\title{
Erratum to: The reach and health impacts of the National Breast and Cervical Cancer Early Detection Program
}

\author{
Gery P. Guy Jr. ${ }^{1}$. Florence K. L. Tangka ${ }^{1} \cdot$ Ingrid J. Hall $^{1} \cdot$ Jacqueline W. Miller $^{1}$ •
} Janet Royalty ${ }^{1}$

Published online: 1 May 2015

(c) Springer International Publishing Switzerland 2015

\section{Erratum to: Cancer Causes Control \\ DOI 10.1007/s10552-015-0561-0}

In the original publication of the article, reference 6 has not been cited properly. The corrected reference is provided below.

\section{Reference}

6. Dalzell LP, Royalty J, Joseph K, Tangka F (2015) Data sources for identifying low-income, uninsured populations: application to public health-National Breast and Cervical Cancer Early Detection Program (NBCCEDP). Cancer Causes Control. doi:10.1007/ s10552-015-0571-y

The online version of the original article can be found under doi:10.1007/s10552-015-0561-0.

Gery P. Guy Jr.

gguy@cdc.gov

1 Division of Cancer Prevention and Control, Centers for

Disease Control and Prevention, Atlanta, GA, USA 